\title{
Industry-wise Dispersion of Investment Returns in Indian CPSEs: Experiential Confirmation on Aggregation
}

\author{
Sudipta Ghosh ${ }^{1} \&$ P. S. Aithal ${ }^{2}$ \\ ${ }^{1}$ Post-Doctoral Fellow, Faculty of Management \& Commerce, Srinivas University, \\ Mangalore, India \\ E-mail: sgcostmanagement@gmail.com \\ ${ }^{2}$ Professor, College of Management \& Commerce, Srinivas University, Mangalore, India \\ OrcidID: 0000-0002-4691-8736; E-mail: psaithal@gmail.com
}

Subject Area: Business Management.

Type of the Paper: Empirical Research.

Type of Review: Peer Reviewed as per $|\mathrm{C}| \mathrm{O}|\mathrm{P}| \mathrm{E} \mid$ guidance.

Indexed In: OpenAIRE.

DOI: https://doi.org/10.5281/zenodo.5998455

Google Scholar Citation: IJAEML

How to Cite this Paper:

Sudipta Ghosh \& Aithal, P. S., (2022). Industry-wise Dispersion of Investment Returns in Indian CPSEs: Experiential Confirmation on Aggregation. International Journal of Applied Engineering and Management Letters (IJAEML), 6(1), 33-42. DOI: https://doi.org/10.5281/zenodo.5998455

International Journal of Applied Engineering and Management Letters (IJAEML)

A Refereed International Journal of Srinivas University, India.

Crossref DOI : $\underline{\text { https://doi.org/10.47992/IJAEML.2581.7000.0118 }}$

(C) With Authors.

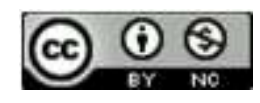

This work is licensed under a Creative Commons Attribution-Non-Commercial 4.0 International License subject to proper citation to the publication source of the work.

Disclaimer: The scholarly papers as reviewed and published by the Srinivas Publications (S.P.), India are the views and opinions of their respective authors and are not the views or opinions of the S.P. The S.P. disclaims of any harm or loss caused due to the published content to any party. 


\title{
Industry-wise Dispersion of Investment Returns in Indian CPSEs: Experiential Confirmation on Aggregation
}

\author{
Sudipta Ghosh ${ }^{1} \&$ P. S. Aithal ${ }^{2}$ \\ ${ }^{1}$ Post-Doctoral Fellow, Faculty of Management \& Commerce, Srinivas University, \\ Mangalore, India \\ E-mail: sgcostmanagement@gmail.com \\ ${ }^{2}$ Professor, College of Management \& Commerce, Srinivas University, Mangalore, India \\ OrcidID: 0000-0002-4691-8736; E-mail: psaithal@gmail.com
}

\begin{abstract}
Purpose: The CPSEs play a vital role in the economic structure of the country by supplying necessary products and services. To sustain in the long run, it is essential to earn a reasonable amount of profit on a consistent basis. Thus, the higher the dispersion in investment returns, the higher is the risk and vice-versa. In this perspective, an industry-wise dispersion of investment returns in Indian CPSEs are carried out from 2010-11 to 2019-20.

Design/Methodology/Approach: To fulfill the research objectives of the study, secondary data is used. Dispersion is calculated for the investment ratios by coefficient of variation. Furthermore, paired ' $t$ ' test is applied to locate any significant transform in the average dispersion of investment returns of all the selected industries taken together. One-way ANOVA is also applied to measure variation in investment returns among the selected industries.

Findings/Result: The study results reveal that the rate of fluctuation in investment returns has varied extensively among the industries. Moreover, most of the selected industries in the $1^{\text {st }}$ sub-period have shown better consistency in investment returns as compared to the $2^{\text {nd }}$ sub-period. Further, significant differences are observed in investment returns among the selected industries, which implies that investment returns in each selected industry has a significant bearing on the aggregate investment returns of the CPSEs.

Originality/Value: To recognize the rate of dispersal in investment returns generated by the CPSEs.
\end{abstract}

Paper Type: Empirical Research.

Keywords: Investment Returns, CPSEs, Dispersion, ROA, ROCE, ROE.

\section{INTRODUCTION :}

Simply defined, investment return is the quantity of profit that is earned by an enterprise from their investment during a particular time period. Alternatively, it is known as ROI. To sustain in the long run, it is essential to earn a reasonable amount of profit on a consistent basis. Thus, higher the dispersion in investment returns, higher is the risk and vice-versa.

The benefits of having consistent ROI are indicated below:

(1) Useful for comparison of funds invested in diverse projects.

(2) Strengthening financial success of the organization.

(3) Useful for comparative analysis between the departments of the company with other companies.

\section{CPSES IN INDIA - A BRIEF OVERVIEW :}

The Central Public Sector Enterprises (CPSEs) were established in India to achieve socio-economic development. At the beginning, the CPSEs had a capital expenditure of Rs. 29 crore, while the capital expenditure was Rs. 16,40,628 crore dated 31.3.2019.

The CPSEs play an imperative function in the financial structure by supplying necessary products and services. They also operate in various competitive markets. From1991-92, the Indian Govt. introduced disinvestment of shares in the CPSEs to build them more efficient and effective in their operational activities. 


\section{PREVIOUS STUDIES :}

An appraisal of previous studies linked to CPSEs is presented below in Table 1.

\begin{tabular}{|c|c|c|}
\hline \multicolumn{3}{|c|}{ Table 1: Appraisal of Previous Studies on CPSEs } \\
\hline S. No. & Focus Area & References \\
\hline 1 & $\begin{array}{l}\text { The study explored the possibility of privatization in PSEs. They } \\
\text { stated that the process of privatization in the industries could make the } \\
\text { most of consumer wellbeing. }\end{array}$ & $\begin{array}{l}\text { Mishra, R.K. and } \\
\text { Nandagopal, R. (1989) } \\
\text { [1] }\end{array}$ \\
\hline 2 & $\begin{array}{l}\text { The sick PSEs should be closed by selling their assets. Such fatally ill } \\
\text { PSEs are mostly limited to those PSEs which were previously } \\
\text { acquired as ill units from the private sector. Hence, these PSEs } \\
\text { became a main issue for the overall substandard performance of the } \\
\text { PSEs. }\end{array}$ & $\begin{array}{l}\text { Gupta, K.L. and Kaur, } \\
\text { H. (2004) [2] }\end{array}$ \\
\hline 3 & $\begin{array}{l}\text { The researcher stated that economic performance is not expected to } \\
\text { be affected by disinvestment because the administration would } \\
\text { continue to be the leading shareholder. The study suggested that } \\
\text { disinvestment could bring positive results in the country provided the } \\
\text { enterprises work in a cutthroat situation. }\end{array}$ & Nagaraj, R. (2005) [3] \\
\hline 4 & $\begin{array}{l}\text { The study examined the outcome of disinvestment of shares on } \\
\text { monetary and on service of cutthroat and dominant units of Indian } \\
\text { PSUs. }\end{array}$ & $\begin{array}{l}\text { Singh, G. and Paliwal, } \\
\text { D. (2010) [4] }\end{array}$ \\
\hline 5 & $\begin{array}{l}\text { The researchers concluded that unsatisfactory result of the disinvested } \\
\text { CPSEs were due to high interference of the administration in the } \\
\text { functioning of CPSEs, inefficient industrial structure, environment } \\
\text { restrictions, and small proportion of disinvestment. }\end{array}$ & $\begin{array}{l}\text { Seema, G., Jain, P.K., } \\
\text { Yadav, S.S., and Gupta, } \\
\text { V.K. (2011) [5] }\end{array}$ \\
\hline 6 & $\begin{array}{l}\text { The study discovered that ONGC, BEL, and RCF were in gray region. } \\
\text { However, SAIL and NTPC were in suffering region. }\end{array}$ & $\begin{array}{l}\text { Pardeshi, B. and Thorat, } \\
\text { H. (2015) [6] }\end{array}$ \\
\hline 7 & $\begin{array}{l}\text { On the whole, the study showed improvement in financial and } \\
\text { operating performance for at least more than } 41 \% \text { of the sample } \\
\text { selected in the study. }\end{array}$ & $\begin{array}{l}\text { Vijayakumar, A. and } \\
\text { Jayachitra, S. (2015) [7] }\end{array}$ \\
\hline 8 & $\begin{array}{l}\text { The study concluded that CPSEs had contributed } 6 \% \text { to } 7 \% \text { of Indias' } \\
\text { GDP, thereby making them an important part of the economic growth } \\
\text { process in the country. }\end{array}$ & Menaka, R. (2015) [8] \\
\hline 9 & $\begin{array}{l}\text { The expansion pace of loss creation CPSEs augmented at an } \\
\text { increasing rate, while the expansion pace of profit creation CPSEs } \\
\text { augmented at a decreasing rate. The study further observed negative } \\
\text { annual growth rate in ROCE which showed lack of efficiency in the } \\
\text { CPSEs. }\end{array}$ & $\begin{array}{l}\text { George, E. and Vinod, } \\
\text { R. (2016) [9] }\end{array}$ \\
\hline 10 & $\begin{array}{l}\text { The study revealed that CPSEs in India have sufficiently maintained } \\
\text { and utilized their cash balances during the period under study. }\end{array}$ & Ghosh, S. (2020) [10] \\
\hline
\end{tabular}

\section{RESEARCH GAP :}

The above review shows that several studies were conducted on various issues related to CPSEs. However, we found no industry-wise studies with respect to dispersion of investment returns in Indian CPSEs. Thus, this paper may well be considered as initial endeavour to add to the existing literature.

\section{OBJECTIVES :}

(1) To examine industry-wise dispersion in investment returns.

(2) To examine whether there is any variation in investment returns among the industries. 


\section{MODEL FOR HYPOTHESES OF THE STUDY :}

6.1 The Model: The model for development of hypotheses is shown below in Fig.1:

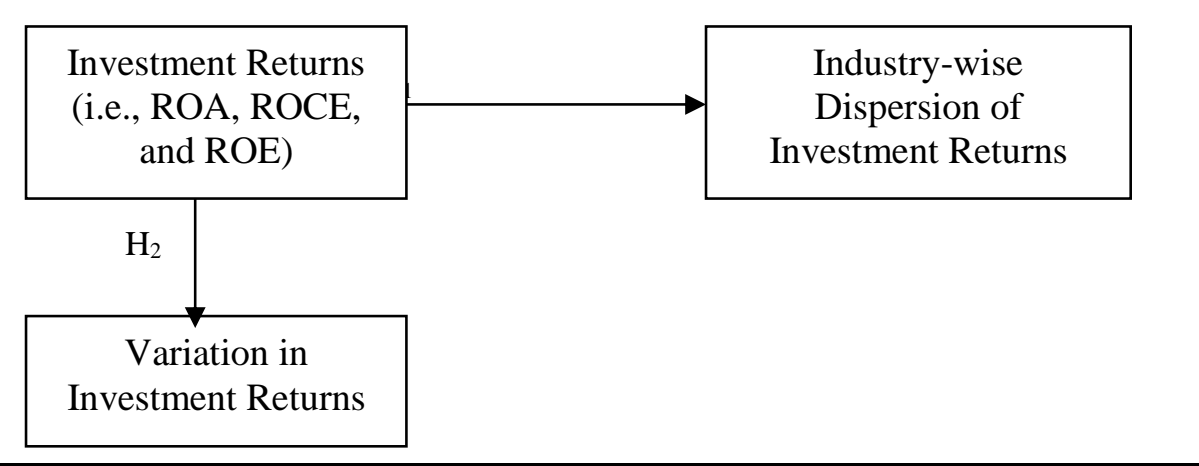

Fig. 1: The Model for Hypotheses Development

6.2 Hypotheses: On the basis of Fig.1, the hypotheses of the study are affirmed underneath: $\mathbf{1}^{\text {st }}$ Hypothesis $\left(\mathrm{H}_{1}\right)$ :

Null Hypothesis $\left(\mathrm{H}_{01}\right)$ : There is no significant change in the average dispersion of investment returns of the total industry.

Alternative Hypothesis $\left(\mathrm{H}_{\mathrm{A} 1}\right)$ : There is significant change in the average dispersion of investment returns of the total industry.

$2^{\text {nd }}$ Hypothesis $\left(\mathbf{H}_{2}\right)$ :

Null Hypothesis $\left(\mathrm{H}_{02}\right)$ : There is no significant variation in investment returns among the industries.

Alternative Hypothesis $\left(\mathrm{H}_{\mathrm{A} 2}\right)$ : There is significant variation in investment returns among the industries.

\section{RESEARCH METHODOLOGY :}

7.1 Sample Frame: The industries selected in the study are shown below in Table 2.

Table 2: CPSEs by Sector and Industry

\begin{tabular}{|c|l|}
\hline \multicolumn{2}{|c|}{ MANUFACTURING SECTOR } \\
\hline 1 & Agro Industry (AI) \\
\hline 2 & Coal Industry (CI) \\
\hline 3 & Crude Oil Industry (COI) \\
\hline 4 & Other Minerals \& Metals Industry (OMMI) \\
\hline 5 & Steel Industry (SI) \\
\hline 6 & Petroleum (Refinery \& Marketing) Industry (PRMI) \\
\hline 7 & Fertilizers Industry (FI) \\
\hline 8 & Chemicals \& Pharmaceuticals Industry (CPI) \\
\hline 9 & Heavy \& Medium Engineering Industry (HMEI) \\
\hline 10 & Transportation Vehicle \& Equipment Industry (TVEI) \\
\hline 11 & Industrial and Consumer Goods Industry (ICGI) \\
\hline 12 & Textiles Industry (TI) \\
\hline 13 & Power Generation Industry (PGI) \\
\hline SERVICE SECTOR \\
\hline 14 & Power Transmission Industry (PTI) \\
\hline 15 & Trading \& Marketing Industry (TMI) \\
\hline 16 & Transport \& Logistic Services Industry (TLSI) \\
\hline 17 & Contract \& Construction and Tech. Consultancy Services Industry (CCTCSI) \\
\hline 18 & Hotel and Tourist Services Industry (HTSI) \\
\hline 19 & Financial Services Industry (FSI) \\
\hline 20 & Telecommunication \& Information Technology Industry (TITI) \\
\hline Source: Published Annual Reports of Public Enterprises Survey, Department of Public Enterprises, Govt. \\
\hline
\end{tabular}


7.2 Study Period: The study period ranges from 2010-2011 to 2019-2020. Further, the whole study period is sub-divided into two sub-periods (i) $1^{\text {st }}$ sub-period: $2010-11$ to $2014-15$ and (ii) $2^{\text {nd }}$ subperiod: 2015-16 to 2019-20.

7.3 Data Source: Secondary data is used which is collected from the published annual reports of the Public Enterprises Survey, Govt. of India. Furthermore, aggregate level data is applied in order to reach at a meaningful conclusion.

7.4 Tools: The following accounting and statistical tools are applied in the study which is stated below:

Accounting Ratios: The investment returns are indicated by the following ratios: [12]

ROA $=$ Net Returns after Levy $\div$ Total Assets

ROCE $=$ EBIT $\div$ Capital Employed

ROE $=$ Net Returns after Levy $\div$ Shareholders' Equity

Coefficient of Variation (C.V.): To capture industry-wise dispersion in investment returns of the CPSEs, C.V. is used which is shown below: [13]

C.V. $=[($ S.D. $) \div$ Mean $] \times 100$

To judge the consistency of investment returns at aggregate level, sector-wise level, and industry-wise level, it has been arbitrarily separated into relatively stable (C.V. $\leq 25 \%)$, moderately fluctuating $(25.1 \% \leq \mathrm{C} . \mathrm{V} . \leq 50.0 \%)$, highly fluctuating $(50.1 \% \leq \mathrm{C} . \mathrm{V} . \leq 75.0 \%)$, and erratically fluctuating $(\mathrm{C} . \mathrm{V}$. $>75.0 \%)$. [14]

Paired 't' Test and One-way ANOVA: Paired ' $t$ ' test has been applied to find out whether there is any significant change in the average dispersion of investment returns of the total industry (i.e., all the selected industries taken together) during the period under study.

The test statistic in this respect is shown below:

$\mathrm{t}=(\overline{\mathrm{d}}) \div(\mathrm{s} \div \sqrt{\mathrm{n}-1})$

Where: $\overline{\mathrm{d}}$ indicates mean and 's' indicates standard deviation of the differences $\mathrm{d}_{\mathrm{i}}$ i.e., $\mathrm{d}=\left(\Sigma \overline{\mathrm{d}_{\mathrm{i}}} \div \mathrm{n}\right)$, and $\mathrm{s}=\sqrt{\sum \mathrm{d}_{\mathrm{i}}^{2} \div \mathrm{n}-\left(\sum \mathrm{d}_{\mathrm{i}} \div \mathrm{n}\right)^{2}}$.

The paired ' $\mathrm{t}$ ' test follows $\mathrm{t}$ allocation with $(\mathrm{n}-1)$ d.f. To examine whether there is any significant variation in investment returns among the selected industries, the method of one-way ANOVA has been employed in the study. For this purpose, average of 10 years investment ratio (i.e., 2010-11 to 2019-20) is calculated for each industry selected in the study [15].

\section{FINDINGS AND ANALYSIS :}

\subsection{Industry-wise Dispersion of Investment Returns:}

8.1.1 Dispersion in ROA: According to Table 3, the lowest variation in ROA (C.V. 7.50\%) is observed in CCTCSI, while TI with C.V. at $1400.00 \%$ reveals highest variation in ROA during the whole period. Moreover, out of twenty industries, fifteen industries (i.e., $75.00 \%$ of the total industries) show low rate of dispersion in ROA than that of average dispersion in ROA of the total industry. On further analysis of Table 3, it is observed that the rate of flux in ROA has varied extensively among the selected industries.

Nine industries (i.e., AI, SI, FI, CPI, ICGI, TI, TMI, TLSI, and HTSI) show erratic fluctuation; six industries (i.e., COI, OMMI, PRMI, HMEI, TVEI, and FSI) reveal moderate fluctuation; four industries (i.e., CI, PGI, PTI, and CCTCSI) show relatively stable performance; and one industry (i.e., TITI) reveals high fluctuation with respect to ROA during the entire study period. The average dispersion of ROA in the total industry is found to be erratic (C.V. 193.42\%) during the entire study period.

In terms of sub-period analysis, eleven industries (i.e., CI, OMMI, SI, PRMI, CPI, TVEI, ICGI, PGI, TLSI, CCTCSI, and FSI) reveal lower variation in ROA during the $1^{\text {st }}$ half as compared to that in the $2^{\text {nd }}$ half, while eight industries (i.e., AI, COI, FI, HMEI, TI, TMI, HTSI, and TITI) have shown lower variation in ROA during the $2^{\text {nd }}$ half as compared to that in the $1^{\text {st }}$ half. The remaining one industry (i.e., PTI) shows same variation in ROA during the two sub-periods.

The average dispersion of ROA (C.V. 98.31\%) of the total industry in the $1^{\text {st }}$ half is found to be higher than that of the average dispersion of ROA (C.V. 80.51\%) of the total industry in the $2^{\text {nd }}$ half. 


\begin{tabular}{|c|c|c|c|c|c|c|}
\hline \multicolumn{7}{|c|}{$\begin{array}{l}\text { Table 3: Dispersion of Investment Returns (represented by ROA) in Selected } \\
\text { Industries during 2010-11 to } 2019-20\end{array}$} \\
\hline \multirow{2}{*}{$\begin{array}{l}\text { Selected } \\
\text { Industries }\end{array}$} & \multicolumn{2}{|c|}{ Whole Period } & \multicolumn{2}{|c|}{$1^{\text {st }}$ Sub-Period } & \multicolumn{2}{|c|}{$2^{\text {nd }}$ Sub-Period } \\
\hline & $\begin{array}{c}\text { C.V. of } \\
\text { ROA } \\
(\%)\end{array}$ & $\begin{array}{c}\begin{array}{c}\text { Nature } \\
\text { of } \\
\text { Dispersion }\end{array} \\
\end{array}$ & $\begin{array}{c}\text { C.V. of } \\
\text { ROA } \\
(\%)\end{array}$ & $\begin{array}{c}\begin{array}{c}\text { Nature } \\
\text { of } \\
\text { Dispersion }\end{array} \\
\end{array}$ & $\begin{array}{c}\text { C.V. of } \\
\text { ROA } \\
(\%)\end{array}$ & $\begin{array}{c}\begin{array}{c}\text { Nature } \\
\text { of } \\
\text { Dispersion }\end{array} \\
\end{array}$ \\
\hline \multicolumn{7}{|c|}{ Manufacturing Sector: } \\
\hline AI & 80.00 & Erratic & 83.33 & Erratic & 66.67 & High \\
\hline CI & 21.05 & Stable & 20.00 & Stable & 22.22 & Stable \\
\hline COI & 50.00 & Moderate & 30.00 & Moderate & 20.00 & Stable \\
\hline OMMI & 33.33 & Moderate & 20.00 & Stable & 37.50 & Moderate \\
\hline SI & 300.00 & Erratic & 66.67 & High & 200.00 & Erratic \\
\hline PRMI & 50.00 & Moderate & 33.33 & Moderate & 50.00 & Moderate \\
\hline FI & 211.11 & Erratic & 287.50 & Erratic & 177.78 & Erratic \\
\hline CPI & 116.67 & Erratic & 75.00 & High & 133.33 & Erratic \\
\hline HMEI & 50.00 & Moderate & 60.00 & High & 25.00 & Stable \\
\hline TVEI & 33.33 & Moderate & 33.33 & Moderate & 50.00 & Moderate \\
\hline ICGI & 83.33 & Erratic & 53.85 & High & 118.18 & Erratic \\
\hline TI & 1400.00 & Erratic & 800.00 & Erratic & 466.67 & Erratic \\
\hline PGI & 20.00 & Stable & 16.67 & Stable & 25.00 & Stable \\
\hline \multicolumn{7}{|c|}{ Service Sector: } \\
\hline PTI & 25.00 & Stable & 25.00 & Stable & 25.00 & Stable \\
\hline TMI & 1000.00 & Erratic & 100.00 & Erratic & 0.00 & - \\
\hline TLSI & 200.00 & Erratic & 40.00 & Moderate & 50.00 & Moderate \\
\hline CCTCSI & 7.50 & Stable & 0.00 & - & 25.00 & Stable \\
\hline HTSI & 80.00 & Erratic & 150.00 & Erratic & 25.00 & Stable \\
\hline FSI & 50.00 & Moderate & 0.00 & - & 50.00 & Moderate \\
\hline TITI & 57.14 & High & 71.43 & High & 42.86 & Moderate \\
\hline Average & 193.42 & Erratic & 98.31 & Erratic & 80.51 & Erratic \\
\hline
\end{tabular}

8.1.2 Dispersion in ROCE: According to Table 4, CCTCSI reveals lowest dispersion in ROCE (C.V. 8.33\%), while TI shows highest dispersion in ROCE (C.V. 800.00\%) during the entire period. Out of twenty industries, sixteen industries (i.e., $80.00 \%$ of the total selected industries) indicate low rate of dispersion in ROCE as compared to the average dispersion in ROCE of the total industry. Further, the rate of fluctuation in ROCE has varied comprehensively among the twenty industries selected in the study.

Seven industries (i.e., AI, SI, FI, CPI, ICGI, TI, and TLSI) indicate erratic fluctuation; four industries (i.e., COI, OMMI, PRMI, and HMEI) show moderate fluctuation; four industries (i.e., TVEI, TMI, HTSI, and TITI) indicate high fluctuation; and five industries (i.e., CI, PGI, PTI, CCTCSI, and FSI) show relatively stable performance in respect of ROCE during the whole period. On the average, investment returns in terms of ROCE of the total industry has fluctuated erratically (C.V. 133.96\%) throughout the entire study period.

On the basis of sub-period analysis, twelve industries (i.e., CI, OMMI, SI, PRMI, CPI, TVEI, ICGI, TI, PGI, PTI, TMI, and FSI) show lower dispersion in ROCE during the $1^{\text {st }}$ sub-period as compared to that in the $2^{\text {nd }}$ sub-period, while seven industries (i.e., AI, FI, HMEI, TLSI, CCTCSI, HTSI, and TITI) show lower dispersion in ROCE during the $2^{\text {nd }}$ sub-period as compared to that in the $1^{\text {st }}$ subperiod of the study. The remaining one industry (i.e., COI) has shown same dispersion in ROCE during the two sub-periods.

The average variation of ROCE (C.V. 107.30\%) of the total industry in the $1^{\text {st }}$ half is found to be lower than that of the average variation of ROCE (C.V. 259.64\%) of the total industry in the $2^{\text {nd }}$ half. 


\begin{tabular}{|c|c|c|c|c|c|c|}
\hline \multicolumn{7}{|c|}{$\begin{array}{l}\text { Table 4: Dispersion of Investment Returns (represented by ROCE) in Selected } \\
\text { Industries during 2010-11 to } 2019-20\end{array}$} \\
\hline \multirow{2}{*}{$\begin{array}{l}\text { Selected } \\
\text { Industries }\end{array}$} & \multicolumn{2}{|c|}{ Whole Period } & \multicolumn{2}{|c|}{$1^{\text {st }}$ Sub-Period } & \multicolumn{2}{|c|}{$2^{\text {nd }}$ Sub-Period } \\
\hline & $\begin{array}{c}\text { C.V. of } \\
\text { ROCE } \\
(\%)\end{array}$ & $\begin{array}{c}\text { Nature } \\
\text { of } \\
\text { Dispersion }\end{array}$ & $\begin{array}{l}\text { C.V. of } \\
\text { ROCE } \\
(\%)\end{array}$ & $\begin{array}{c}\begin{array}{c}\text { Nature } \\
\text { of } \\
\text { Dispersion }\end{array} \\
\end{array}$ & $\begin{array}{l}\text { C.V. of } \\
\text { ROCE } \\
(\%)\end{array}$ & $\begin{array}{c}\begin{array}{c}\text { Nature } \\
\text { of } \\
\text { Dispersion }\end{array} \\
\end{array}$ \\
\hline \multicolumn{7}{|c|}{ Manufacturing Sector: } \\
\hline AI & 600.00 & Erratic & 700.00 & Erratic & 100.00 & Erratic \\
\hline CI & 20.00 & Stable & 10.53 & Stable & 25.81 & Moderate \\
\hline COI & 38.46 & Moderate & 22.22 & Stable & 22.22 & Stable \\
\hline OMMI & 33.33 & Moderate & 19.23 & Stable & 31.25 & Moderate \\
\hline SI & 120.00 & Erratic & 33.33 & Moderate & 600.00 & Erratic \\
\hline PRMI & 46.67 & Moderate & 23.08 & Stable & 52.94 & High \\
\hline FI & 120.00 & Erratic & 132.26 & Erratic & 124.14 & Erratic \\
\hline CPI & 280.00 & Erratic & 163.64 & Erratic & 350.00 & Erratic \\
\hline HMEI & 33.33 & Moderate & 41.67 & Moderate & 25.00 & Stable \\
\hline TVEI & 60.00 & High & 6.67 & Stable & 40.00 & Moderate \\
\hline ICGI & 192.31 & Erratic & 139.13 & Erratic & 266.67 & Erratic \\
\hline TI & 800.00 & Erratic & 425.00 & Erratic & 3300.00 & Erratic \\
\hline PGI & 11.11 & Stable & 10.00 & Stable & 12.50 & Stable \\
\hline \multicolumn{7}{|c|}{ Service Sector: } \\
\hline PTI & 11.11 & Stable & 0.00 & - & 11.11 & Stable \\
\hline TMI & 64.00 & High & 33.33 & Moderate & 94.12 & Erratic \\
\hline TLSI & 85.71 & Erratic & 200.00 & Erratic & 8.33 & Stable \\
\hline CCTCSI & 8.33 & Stable & 18.18 & Stable & 8.33 & Stable \\
\hline HTSI & 68.18 & High & 63.64 & High & 35.29 & Moderate \\
\hline FSI & 20.00 & Stable & 16.67 & Stable & 25.00 & Stable \\
\hline TITI & 66.67 & High & 87.50 & Erratic & 60.00 & High \\
\hline Average & 133.96 & Erratic & 107.30 & Erratic & 259.64 & Erratic \\
\hline
\end{tabular}

8.1.3 Dispersion in ROE: From Table 5, it is observed that PGI shows lowest variation in ROE (C.V. $10.00 \%$ ), while SI shows highest variation in ROE (C.V. 800.00\%) during the whole period. It is further observed that out of twenty industries, sixteen industries (i.e., $80.00 \%$ of the total selected industries) reveal low rate of dispersal in ROE as compared to the average dispersal in ROE of the total industry. Furthermore, the rate of fluctuation in ROE has varied widely among the twenty industries under study.

Nine industries (i.e., AI, SI, FI, CPI, ICGI, TI, TMI, TLSI, and HTSI) show erratic fluctuation; three industries (i.e., COI, OMMI, and PRMI) reveal moderate fluctuation; three industries (i.e., HMEI, TVEI, and TITI) show high fluctuation; and five industries (i.e., CI, PGI, PTI, CCTCSI, and FSI) indicate relatively stable performance with respect to ROE during the entire study period. The average ROE of the total industry has fluctuated erratically (C.V. 171.84\%) during the entire study period. So far as the sub-period analysis of ROE is concerned, ten industries (i.e., OMMI, SI, PRMI, CPI, TVEI, ICGI, PGI, TMI, FSI, and TITI) show lower dispersal in ROE during the $1^{\text {st }}$ half as compared to that in the $2^{\text {nd }}$ half, while nine industries (i.e., AI, CI, FI, HMEI, TI, PTI, TLSI, CCTCSI, and HTSI) indicate lower dispersal in ROE during the $2^{\text {nd }}$ half as compared to that in the $1^{\text {st }}$ half. The remaining one industry (i.e., COI) shows same dispersion in ROE (i.e., 25.00\%) during the two sub-periods. The average dispersion of ROE (C.V. 73.23\%) of the total industry in the $2^{\text {nd }}$ half is found to be lower as compared to the average dispersion of ROE (C.V. 126.40\%) of the total industry in the $1^{\text {st }}$ half. 


\begin{tabular}{|c|c|c|c|c|c|c|}
\hline \multicolumn{7}{|c|}{$\begin{array}{c}\text { Table 5: Dispersion of Investment Returns (represented by ROE) in Selected } \\
\text { Industries during } 2010-11 \text { to } 2019-20\end{array}$} \\
\hline \multirow{2}{*}{$\begin{array}{l}\text { Selected } \\
\text { Industries }\end{array}$} & \multicolumn{2}{|c|}{ Whole Period } & \multicolumn{2}{|c|}{$1^{\text {st }}$ Sub-Period } & \multicolumn{2}{|c|}{$2^{\text {nd }}$ Sub-Period } \\
\hline & $\begin{array}{c}\text { C.V.of } \\
\text { ROE } \\
(\%)\end{array}$ & $\begin{array}{c}\text { Nature } \\
\text { of } \\
\text { Dispersion }\end{array}$ & $\begin{array}{c}\text { C.V. of } \\
\text { ROE } \\
(\%)\end{array}$ & $\begin{array}{c}\text { Nature } \\
\text { of } \\
\text { Dispersion }\end{array}$ & $\begin{array}{c}\text { C.V. of } \\
\text { ROE } \\
(\%)\end{array}$ & $\begin{array}{c}\begin{array}{c}\text { Nature } \\
\text { of } \\
\text { Dispersion }\end{array} \\
\end{array}$ \\
\hline \multicolumn{7}{|c|}{ Manufacturing Sector: } \\
\hline AI & 162.79 & Erratic & 139.71 & Erratic & 82.35 & Erratic \\
\hline $\mathrm{CI}$ & 19.67 & Stable & 11.54 & Stable & 11.43 & Stable \\
\hline COI & 41.67 & Moderate & 25.00 & Stable & 25.00 & Stable \\
\hline OMMI & 35.71 & Moderate & 16.67 & Stable & 27.27 & Stable \\
\hline SI & 800.00 & Erratic & 42.86 & Moderate & 120.00 & Erratic \\
\hline PRMI & 50.00 & Moderate & 27.27 & Stable & 56.25 & Moderate \\
\hline FI & 780.00 & Erratic & 195.12 & Erratic & 181.69 & Erratic \\
\hline CPI & 80.00 & Erratic & 72.22 & High & 100.00 & Erratic \\
\hline HMEI & 53.33 & High & 61.11 & High & 36.36 & Moderate \\
\hline TVEI & 72.73 & High & 21.05 & Stable & 25.00 & Stable \\
\hline ICGI & 82.35 & Erratic & 11.54 & Stable & 175.00 & Erratic \\
\hline TI & 540.00 & Erratic & 1600.00 & Erratic & 300.00 & Erratic \\
\hline PGI & 10.00 & Stable & 9.09 & Stable & 10.00 & Stable \\
\hline \multicolumn{7}{|c|}{ Service Sector: } \\
\hline PTI & 13.33 & Stable & 7.14 & Stable & 6.25 & Stable \\
\hline TMI & 366.67 & Erratic & 40.00 & Moderate & 120.00 & Erratic \\
\hline TLSI & 143.24 & Erratic & 51.25 & High & 50.00 & Moderate \\
\hline CCTCSI & 20.00 & Stable & 11.11 & Stable & 7.69 & Stable \\
\hline HTSI & 81.25 & Erratic & 114.29 & Erratic & 40.00 & Moderate \\
\hline FSI & 15.38 & Stable & 6.67 & Stable & 16.67 & Stable \\
\hline TITI & 68.75 & High & 64.29 & High & 73.68 & High \\
\hline Average & 171.84 & Erratic & 126.40 & Erratic & 73.23 & High \\
\hline
\end{tabular}

8.2 Paired ' $t$ ' Test for Dispersion in Investment Returns: To examine whether there is any noteworthy change in the average dispersion of investment returns of the total industry between the two sub-periods, paired ' $t$ ' test is employed in the study. Table 6 reveals insignificant results for ROA $(\mathrm{t}=0.83)$, ROCE $(\mathrm{t}=-1.01)$, and ROE $(\mathrm{t}=0.80)$. Thus, paired ' $\mathrm{t}$ ' test leads to the acceptance of the first null hypothesis of the study.

\begin{tabular}{|c|c|c|c|}
\hline \multicolumn{4}{|c|}{$\begin{array}{l}\text { Table 6: Paired ' } \mathrm{t} \text { ' Test for Dispersion in Investment Returns of Selected Industries } \\
\text { during } 2010-11 \text { to } 2019-20\end{array}$} \\
\hline \multirow[b]{2}{*}{ Particulars } & \multicolumn{3}{|c|}{ Coefficient of Variation (C.V.) } \\
\hline & $\begin{array}{c}\text { ROA } \\
(\%)\end{array}$ & $\begin{array}{c}\text { ROCE } \\
(\%)\end{array}$ & $\begin{array}{c}\text { ROE } \\
(\%)\end{array}$ \\
\hline Average C.V. ( $1^{\text {st }}$ Sub-Period $)$ & 98.31 & 107.30 & 126.40 \\
\hline Average C.V. ( $2^{\text {nd }}$ Sub-Period $)$ & 80.51 & 259.64 & 73.23 \\
\hline Calculated value of $\mathrm{t}$ & $0.83^{\mathrm{i}}$ & $-1.01^{\mathrm{i}}$ & $0.80^{\mathrm{i}}$ \\
\hline \multicolumn{4}{|l|}{ i insignificant. } \\
\hline Source: Author's Calculation. & & & \\
\hline
\end{tabular}

8.3 Variation in Investment Returns among the Selected Industries: Table 7 reveals significant results at $1 \%$ level for all the selected investment ratios (i.e., ROA, ROCE, and ROE) of the study, thereby leading to the rejection of the second null hypothesis of the study. This implies that there are momentous differences in investment returns among the selected industries during the period under study. 


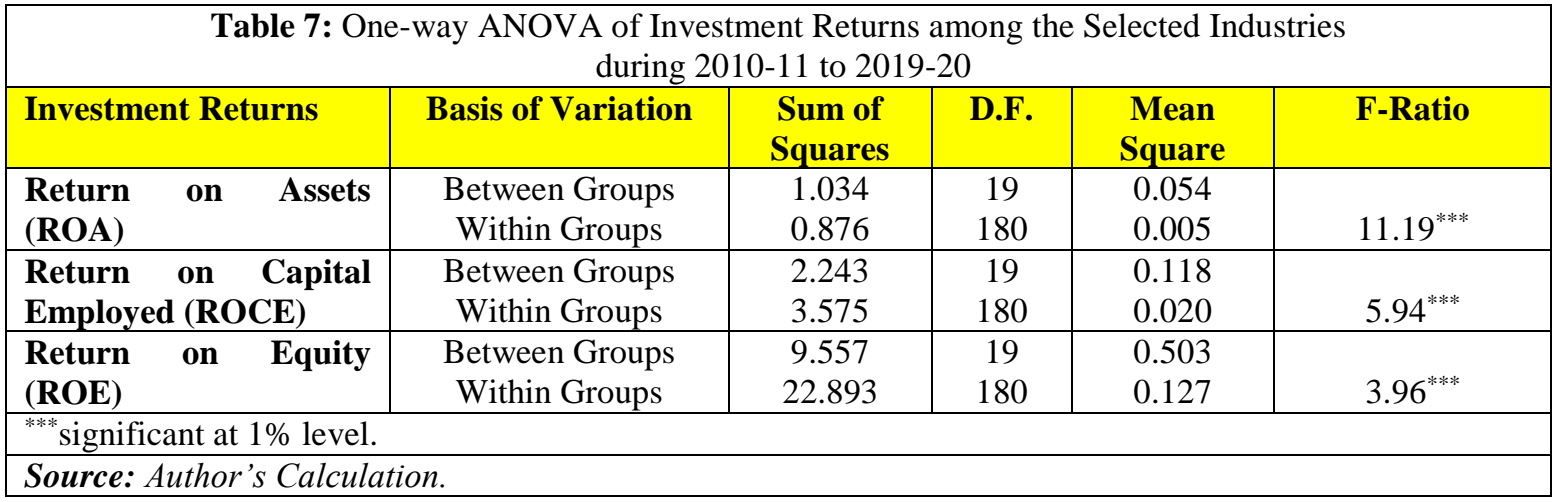

8.4 Results of the Model: The results of the model based on established hypotheses are shown below in Fig. 2:

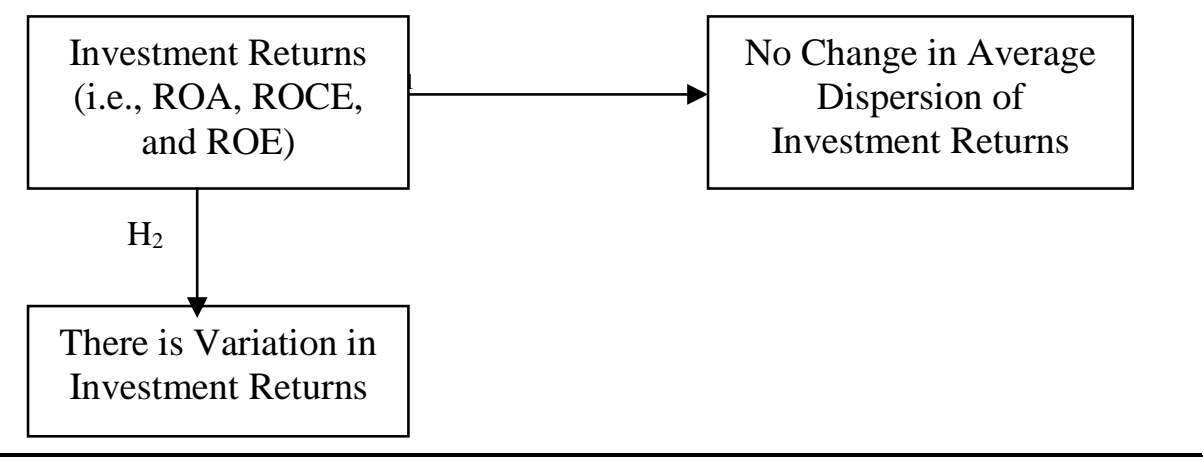

Fig. 2: Results of the Model based on established Hypotheses of the Study

\section{CONCLUSIONS :}

The above analysis of dispersion in investment returns reveals that the rate of fluctuation in investment returns has varied extensively among the industries selected in the study. Moreover, majority of the selected industries in the $1^{\text {st }}$ half has shown better consistency in investment returns than that of the $2^{\text {nd }}$ half.

Further, the study indicates significant differences in investment returns among the selected industries throughout the period under study. Thus, investment returns in each selected industry has a significant bearing on the aggregate investment returns of the CPSEs.

\section{RECOMMENDATION :}

The investment returns have fluctuated widely among the selected industries. Moreover, there are variations in investment returns among the selected industries. Hence, necessary measures should be adopted to ensure consistent returns on investment for sustainable growth of the CPSEs in the long run.

\section{REFERENCES :}

[1] Mishra, R. K. and Nandagopal, R. (1989). Capital Market and Privatization of Public Enterprises: The Case of India. Institute of Public Enterprises and Bobolinks Corp., India, 123150.

[2] Gupta, K. L. and Kaur, H. (2004). New Indian Economy and Reforms. Deep and Deep Publication Pvt. Ltd., New Delhi, India, 80-113.

[3] Nagaraj, R. (2005). Disinvestment and Privatization in India - Assessment and Options. Paper prepared for the Asian Development Bank Policy Networking Project, New Delhi, 1-40.

[4] Singh, G. and Paliwal, D. (2010). Impact of Disinvestment on the Financial and Operating Performance of Competitive and Monopoly Units of Indian Public Sector Enterprises. International Journal of Research in Commerce \& Management, 1(2), 40-57. 
Google Scholar 7

[5] Seema, G., Jain, P. K., Yadav, S. S., and Gupta, V. K. (2011). Financial Performance of Disinvested Central Public Sector Enterprises in India: An Empirical Study on Select Dimensions. Journal of Applied Finance \& Banking, 1(4), 57-106.

Google Scholar $\chi^{\top}$

[6] Pardeshi, B. and Thorat, H. (2015). Evaluating the Financial Health of Central Public Sector Enterprises in India through Z Score Model. Twelfth AIMS International Conference on Management. Available at: https://papers.ssrn.com/sol3/papers.cfm?abstract_id=3451119 (retrieved on 18.6.21), 1725-1730.

Google Scholar ${ }^{7}$

[7] Vijayakumar, A. and Jayachitra, S. (2015). Financial and Operating Performance of Disinvested Central Public Sector Enterprises of Manufacturing Sector in India. International Journal of Research in Commerce, IT \& Management, 5(1), 38-46.

Google Scholar X'

[8] Menaka, R. (2015). Financial Performance of Navratna Companies in India - Central Public Sector. Journal in Management and Social Science, 3(3), 488-504.

Google Scholar $\chi^{\top}$

[9] George, E. and Vinod, R. (2016). A Study on the Performance of Central Public Sector Enterprises in India. International Journal of Engineering Science and Computing, 6(5), 52675271.

Google Scholar X

[10] Ghosh, S. (2020). Cash Management of Central Public Sector Enterprises in India: A Macro Level Study. PIMT Journal of Research, 12(3), 30-34. Google Scholar $X^{\top}$

[11] Published Annual Reports of Public Enterprises Survey (2010-11 to 2019-20), Department of Public Enterprises, Government of India, New Delhi.

[12] Khan, M. Y. and Jain, P. K. (1994). Financial Management - Text and Problems. $2^{\text {nd }}$ Edition. Tata McGraw-Hill Publishing Company Limited, New Delhi. pp. 103-106.

[13] Ghosh, R. and Saha, S. (1987). Business Mathematics \& Statistics (Book - I). $5^{\text {th }}$ Edition. New Central Book Agency, Kolkata, 145-146.

[14] Selvi, A. M. and Vijayakumar, A. (2007). Structure of Profit Rates in Indian Automobile Industries - A Comparison. The Management Accountant, 42(10), 784-789.

Google Scholar $X^{\top}$

[15] Das, N. G. (1990). Statistical Methods (Vol. II). M. Das \& Co., Kolkata, 260-303. 